\title{
A REU-Site Program for Engineering Education Research on Self-Regulated Learning
}

\section{Prof. Ning Fang, Utah State University}

Ning Fang is a Professor in the College of Engineering at Utah State University, USA. He has taught a variety of courses at both graduate and undergraduate levels, such as engineering dynamics, metal machining, and design for manufacturing. His areas of interest include computer-assisted instructional technology, curricular reform in engineering education, the modeling and optimization of manufacturing processes, and lean product design. He earned his $\mathrm{PhD}$, MS, and BS degrees in mechanical engineering and is the author of more than 60 technical papers published in refereed international journals and conference proceedings. He is a Senior Member of the Society for Manufacturing Engineering, a member of the American Society of Mechanical Engineers, and a member of the American Society for Engineering Education.

\section{Dr. Oenardi Lawanto, Utah State University}

Dr. Oenardi Lawanto is an associate professor in the Department of Engineering Education at Utah State University, USA. He received his B.S.E.E. from Iowa State University, his M.S.E.E. from the University of Dayton, and his Ph.D. from the University of Illinois at Urbana-Champaign. Before coming to Utah State, Dr. Lawanto taught and held several administrative positions at one large private university in Indonesia. He has developed and delivered numerous international workshops on student-centered learning and online learning-related topics during his service. Dr. Lawanto's research interests include cognition, learning, and instruction, and online learning.

\section{Prof. Kurt Henry Becker, Utah State University - Engineering Education}

Kurt Becker is the current director for the Center for Engineering Education Research (CEER) which examines innovative and effective engineering education practices as well as classroom technologies that advance learning and teaching in engineering. He is also working on National Science Foundation (NSF) funded projects exploring engineering design thinking. His areas of research include engineering design thinking, adult learning cognition, engineering education professional development and technical training. He has extensive international experience working on technical training and engineering educaton projects funded by the Asian Development Bank, World Bank, and U.S. Department of Labor, USAID. Countries where he has worked include Armenia, Bangladesh, Bulgaria, China, Macedonia, Poland, Romania, and Thailand. In addition, he teaches undergraduate and graduate courses for the Department of Engineering Education at Utah State University. 


\title{
A REU Site Program for Engineering Education Research on Self-Regulated Learning
}

\begin{abstract}
This paper reports some results of an ongoing REU Site program funded by the NSF TUES-Type 1 funds. The vast majority of NSF-funded REU Site programs focus on disciplinary research in Science, Technology, Engineering, and Mathematics (STEM). REU Site programs that focus on engineering education research have not been made available until recently. In this paper, we report the results of a 10-week summer REU Site program that focuses on engineering education research on self-regulated learning. In addition to the description of the theoretical foundation and the overall framework of this program, this paper describes its three primary elements including: 1) recruitment and selection of REU participants, 2) REU research projects, and 3) seminar and workshop series and a final symposium. Selected student comments, as well as lessons learned, are also presented in this paper. Many REU students expressed their desire to pursue further graduate studies, or teaching, to advance their professional careers.
\end{abstract}

\section{Introduction}

Extensive research evidence has suggested that undergraduate research experience (REU) significantly improves students' academic performance and confidence, and has a lasting impact on their career paths ${ }^{1-3}$. The National Science Foundation has been supporting undergraduate research in two ways: 1) REU Supplements to existing NSF grant awards, which usually involve one to two undergraduates per grant award, and 2) REU Sites that provide support for a cohort of undergraduates (six to ten per year) over a three-year project period ${ }^{4}$. REU Sites program can be either a summer program (i.e., REU students conduct research in summer at the project PIs' institutions) or an academic year program (i.e., REU students conduct research throughout an academic year with the supervisions of the project PIs).

The vast majority of NSF-funded REU Site programs focus on disciplinary research in Science, Technology, Engineering, and Mathematics (STEM), such as research in mechanical engineering, civil engineering, environment engineering, electrical engineering, computer sciences, mathematics, technology, and physical sciences ${ }^{5-12}$. For example, Castillejos 5 reported a REU Site program focused on neural engineering. REU students worked on projects that involved materials for neural tissue engineering, neurofunctional and neurobehavior analysis, multicellular neural tissue engineering, and neuromuscular control. Lunardi ${ }^{6}$ reported a REU Site program focused on integrating scalable renewable generating energy sources into an efficient power electric grid. REU students worked on a variety of research projects such as novel materials for inexpensive photovoltaics, nanoparticles/metal oxide coated polymer fibers for solar cells, and characterization of high voltage diodes.

REU Site programs that focus on engineering education research have not been made available until recently. Therefore, the literature on REU Site programs that focus on engineering education research is limited. In this paper, we report the results of a 10-week summer REU Site program that focuses on engineering education research, particularly on self-regulated learning 
(SRL). The program, funded through the NSF-TUES Type 1 funds, aims to motivate and retain talented undergraduates in STEM careers, particularly careers in teaching and STEM education research.

The remaining sections of this paper are organized as follows. First, self-regulated learning is briefly introduced to provide a theoretical foundation of this REU Site program. Then, the goal, objectives, and overall framework of the program are described. Next, three primary elements of the program are described, including 1) recruitment and selection of REU participants; 2) REU research projects; and 3) seminar and workshop series and a final symposium. Then, the results of student evaluation of the program, as well as lessons learned, are described in the end of the paper. Finally, concluding remarks are made at the end of the paper.

\section{Self-Regulated Learning (SRL)}

The theoretical foundation of this REU Site program is self-regulated learning (SRL) theory. SRL refers to learners' ability and skills to understand and control their learning environment. Zimmerman ${ }^{13}$ defined SRL as learners' "self-generated thoughts, feelings, and actions which are systematically oriented toward attainment of their goals." Self-regulated learners are "metacognitively, motivationally, and behaviorally active participants in their own learning process" 13; therefore, self-regulated learners are skilled in goal-setting, self-monitoring, selfinstruction, and self-reinforcement ${ }^{14}$.

Evidence has shown that SRL plays an increasingly important role in the education of both children and adults, and that SRL is a significant predictor of students' academic performance. For example, Zheng et al. ${ }^{15}$ have applied a SRL process model to improve students' mastery of engineering concepts. Zimmerman and Martinez-Pons ${ }^{16}$, Zimmerman ${ }^{17}$, and Lawanto et al. ${ }^{18}$ also found a significant co-relationship between student achievement and the SRL strategies that students employed.

While many theoretical perspectives on self-regulation have been offered in the literature, this REU Site program is built particularly upon Butler and Cartier's socio-constructivist model of self-regulation ${ }^{19-21}$ because it enables teasing apart and investigating the interplay between metacognitive knowledge (e.g., students' understanding about tasks and strategies as mediating variables), and metacognitive control, conceptualized as cycles of "self-regulation in action," within the context of complex learning activity. Butler and Cartier's model ${ }^{19-21}$ depicts eight features that interact with each other to shape engagement in learning: layers of context, what individuals bring, mediating variables, task interpretation, personal objectives, SRL processes, cognitive strategies, and performance criteria. Interested readers may refer to relevant literature to gain an in-depth understanding of Butler and Cartier's model ${ }^{19-21}$.

\section{Goal, Objectives, and Overall Framework of the REU Site Program}

The overall goal of this REU Site program is to motivate and retain talented undergraduates in STEM careers, particularly careers in teaching and STEM education research. The specific objectives of the program include: 
- $\quad$ Expose REU students, especially those who might not otherwise have the opportunity and those from underrepresented groups (female and ethnic minority), to cutting-edge STEM education research.

- $\quad$ Stimulate participating REU students to pursue graduate degrees and careers in teaching and STEM education research.

- Develop each REU student's technical, communication, and teamwork skills by actively engaging them in all aspects of educational research - from literature review, research methods, data collection and analysis, to technical writing and oral presentations.

- Create a supportive educational community that involves REU students, graduate students, faculty mentors, and education professionals and administrators to promote STEM education.

- Evaluate the effectiveness of this REU Site program and broadly disseminate student research findings as well as the program results to the STEM research and education community nationwide.

The overall framework of the program is described as follow. Over a three-year period starting summer 2014, 24 REU students (eight per year) from across the nation actively participate in the program on engineering education research. The program consists of four research projects particularly designed for REU students. Each project team includes a faculty advisor, a graduate student mentor, and two REU students. These four REU research projects share a common intellectual focus: self-regulated learning in engineering education. In addition to research, REU students participate in five seminars and workshops, a final research symposium, and formative and summative program evaluations.

\section{Student Recruitment and Selection}

Advertisement for the program was done via a variety of channels, such as email distributions to targeted institutions, a variety of list serves, as well as personal contacts. Due to aggressive advertising efforts, 86 applications from across the country were received for the summer 2014 program, which was the first summer of the program. Each applicant was required to submit the following items:

1. Application form

2. A statement of one to two pages that describe

1) The applicant's career goal and professional interest

2) Why the applicant is interested in this REU Site program

3) The applicant's previous research experience (if any) and academic accomplishments (such as awards and honors)

4) What the applicant expects to learn from this REU Site experience

5) Was there anyone whom inspired the applicant participating in this REU Site? If "yes", what was applicant's relationship with him (or her)?

3. Resume listing prior study and work experience and accomplishments

4. A copy of the applicant's recent unofficial transcript of all college course work

5. Two letters of recommendation. The letters must be from professionals (rather than personal friends or relatives) who can comment on the applicant's accomplishments, or on the applicant's potential as an undergraduate researcher. 
Among 86 applications, 76 were considered complete and included all above-listed items. Table 1 shows the demographic locations (from 24 states) of the 76 complete applications.

Table 1. The demographic locations of the 76 complete applications

\begin{tabular}{|l|c|l|c|l|c|}
\hline State & $\begin{array}{c}\text { Number of } \\
\text { applicants }\end{array}$ & State & $\begin{array}{c}\text { Number of } \\
\text { applicants }\end{array}$ & State & $\begin{array}{c}\text { Number of } \\
\text { applicants }\end{array}$ \\
\hline California & 3 & Maryland & 3 & Ohio & 1 \\
\hline Colorado & 1 & Michigan & 1 & Oklahoma & 2 \\
\hline Georgia & 2 & Missouri & 1 & Oregon & 2 \\
\hline Iowa & 1 & Mississippi & 6 & Pennsylvania & 1 \\
\hline Idaho & 2 & North Carolina & 3 & Tennessee & 1 \\
\hline Indiana & 1 & New Jersey & 1 & Texas & 5 \\
\hline Louisiana & 4 & New Mexico & 2 & Utah & 19 \\
\hline Massachusetts & 3 & New York & 3 & Washington & 2 \\
\hline
\end{tabular}

Among the 76 valid applicants who were from 43 institutions across the country, eight undergraduate students from eight different institutions were finally selected, based on a comprehensive selection rubric, to participate in the summer 2014 program on the campus of the University. These students had diverse backgrounds in a variety of STEM fields and were from either 4-year or 2-year institutions. Among the eight REU students, five were females and three were males.

\section{REU Research Projects}

Throughout the 10-week summer program, REU students conducted four research projects, including 1) developing a self-regulation survey instrument for problem solving in engineering; 2) studying students' meta-cognitive strategies when learning engineering with computer simulation and animation; 3) studying students' self-efficacy, perception of engineering, and engineering interest in the context of Mathematics Engineering Science Achievement (MESA) 22; and 4) developing an instrument for exploring engineering design knowing and thinking. These four projects are briefly described in the following paragraphs.

Project 1 aims to develop a survey instrument to measure how well students regulate themselves in solving ill-defined engineering problems. In summer 2014, two REU students who worked on project 1 particularly focused on three important constructs of self-regulated learning: task value, task interpretation, and planning strategies. The project team, which included a faculty mentor, a graduate student mentor, and two REU students, designed and implemented the following research methodology: chose targeted SRL construct, designed problems and interview questions for initial study, lined up and interviewed participants, gathered and analyzed data, and developed survey items.

Project 2 aims to study the effect of computer simulation and animation on students' metacognitive knowledge and strategies in engineering dynamics, a foundational yet difficult undergraduate engineering course. The project team designed the following two research questions: What metacognitive knowledge do students use in solving engineering dynamics 
problems with a computer simulation and animation module? How do computer simulation and animation modules affect the metacognitive knowledge and skills of students in solving engineering dynamics problems? The REU students applied qualitative research methodology to answer these research questions.

Project 3 aims to identify student-oriented activities, within the Mathematics, Engineering, Science Achievement (MESA) program, that have a positive influence on underrepresented students' engineering self-efficacy, interest in engineering, perceptions of engineering, selfregulating, and cognitive strategies while they are engaged in MESA' hands-on activities. The project team designed six research questions. Three example research questions are: Is there any relationship between MESA activities and the students' self-efficacy? How do MESA activities, self-efficacy, engineering interest, and the perception of engineering influence the students' major choice? What is the relationship between MESA advising and the students' future plans? The REU students performed statistical analysis on relevant data collected through the MESA program.

Project 4 aims to develop an instrument for exploring engineering design knowing and thinking. The REU students studied trends in the cumulative design issues by freshmen, seniors, and professional engineers. The project team classified design issues in the following six categories: requirements, function, expected behavior, structure, behavior derived from structure, and documentation. These six categories were employed in the REU students' coding system.

\section{Seminar and Workshop Series and Final Symposium}

During the first five weeks of the summer 2014 program, the faculty team conducted five seminar and workshop series, including 1) self-regulated learning and its role in engineering education; 2) responsible research; 3) developing an educational research question; 4) mixed methods research methodologies with emphasis on qualitative method; and 5) educational data analysis with SPSS. Two example seminars and workshops are described in the following paragraphs.

Example 1: One seminar focused on the introduction to self-regulated learning and its role in engineering education. The objective of this seminar was to introduce REU participants a broad understanding of the self-regulated learning and its role in learning, teaching, and assessment. In this seminar, each participant was also invited to identify, exercise, and share their own selfregulation to others through working on several pre-developed case studies provided to them.

Example 2: One workshop focused on developing an educational research question. The workshop took the format of "Think-Pair-Share-Report." The faculty organizer first described the general process of educational research. Then, he presented to the REU students the following questions: What are "quality" questions for educational research? How to develop "quality" questions for educational research? How to answer research questions? Selected papers from the literature were also provided to the REU students for them to identify how to answer these questions. 
The capstone event of the REU Site program occurs near the end of the program when a formal symposium on engineering education research is organized. All REU students present their research projects and results in the symposium to faculty mentors and graduate student mentors.

\section{Student Evaluations and Lessons Learned}

The REU students provided evaluations throughout the program. In their final reports, they described what they had learned from this REU program and the impact of the program. Student evaluations were positive. Selected comments from REU students are provided in the following paragraphs:

- "My time spent this summer at [host institution] campus has been filled with many wonderful, incredible, and intelligent people. I have appreciated the experience of spending time with so many people from so many different backgrounds and cultures and with so much to offer. I have gained a new appreciation for the world of academia."

- "This project was one of the best learning experiences that I have encountered in my academic career. My previous research experience has been in the field of mathematics. I was dealing with formulas, equations, and theorems. This is the first time that I have worked with human subject and qualitative data. I realized how hard it is to work with human subjects."

- "This project has impacted my life in a variety of positive ways. All of the outcomes from the last ten weeks have reinforced my want to attend graduate school in some type of educational field. Learning so much about SRL has also made me want to incorporate more self-regulating strategies into my own life."

Based on experiences in the summer 2014 program, the faculty mentor team learned two lessons. First, the decision to accept an applicant to participate in the program should be made as early as possible. This would help prevent highly-qualified applicants from accepting other job offers. Second, it would be better to conduct the five seminar and workshop series within the first two or three weeks, rather than five weeks, of the program. REU students reported that they would understand more about education research if these seminars and workshops could be offered earlier.

\section{Concluding Remarks}

The vast majority of NSF-funded REU Site programs focus on disciplinary research in the STEM field. In this paper, we have reported the results of the 10-week summer REU Site program that focuses on engineering education research, particularly on self-regulated learning. In summer 2014, eight undergraduate applicants from eight institutions across the nation were selected (from 76 applications representing 43 higher-learning institutions and 24 states across the nation) to participate in this REU Site program. REU students worked on four research projects that focused on self-regulated learning. Five seminars and workshops were also provided to the REU students. Student evaluations were positive, and they reported that they have learned a lot about engineering education research from this program. Many students 
expressed their desire to purchase further graduate studies, or teaching, in the development of their professional careers.

\section{Acknowledgements}

This material is based upon work supported by the National Science Foundation under Grant No. DUE 1262806. Graduate students Mr. Andreas Febrian, Mr. Moe Tajvidi, Mr. Presentacion Rivera-Reyes, and Ms. Ting Song are acknowledged for their efforts in mentoring REU students. The project external evaluator Dr. Margaret Lubke is also acknowledged for her efforts in conducting independent evaluation of this program.

\section{Bibliography}

[1] Hathaway, R. S., Naqda, B. A., and Gregerman, S. R., 2002, “The Relationship of Undergraduate Research Participation to Graduate and Professional Education Pursuit: An Empirical Study," Journal of College Student Development, Vol. 43(5), pp. 614-631.

[2] Jones, M. T., Barlow, A. E. L., and Villarejo, M., 2010, "Importance of Undergraduate Research for Minority Persistence and Achievement in Biology," Journal of Higher Education, Vol. 81(1), pp. 82-115.

[3] Zydney, A. L., Bennett, J. S., Shahid, A., and Bauer, K. W., 2002, "Impact of Undergraduate Research Experience in Engineering," Journal of Engineering Education, Vol. 91(2), pp. 151-157.

[4] National Science Foundation, Research Experiences for Undergraduates (REU) Program Solicitation NSF 13542, 2013, available at http://www.nsf.gov/pubs/2013/nsf13542/nsf13542.htm.

[5] Castillejos, R. P., 2014, "NSFREU Site on Neural Engineering: Aiming at High Research Standards (Work in Progress)," Proceedings of the 2014 ASEE Annual Conference \& Exposition, Indianapolis, IN.

[6] Lunardi, L., "Undergraduate Research and the Smart Grid: REU-Site: Engineering the Grid," Proceedings of the 2013 ASEE Annual Conference \& Exposition, Atlanta, Georgia.

[7] Anagnos, T., Lyman-Holt, A. L., and Brophy, S. P., 2012, "WIP: Linking a Geographically Distributed REU Program with Networking and Collaboration Tools," Proceedings of the 2012 ASEE Annual Conference \& Exposition, San Antonio, Texas.

[8] Mahmud, S. M., and Xu, C. Z., 2010, "REU Program in Telematics and Cyber Physical Systems (TCPS): Sharing Strategies, Experience and Lessons Learned to Help Others," Proceedings of the 2010 ASEE Annual Conference \& Exposition, Louisville, KY.

[9] Gilbert, S., Shill, P., and Saunders, K., 2009, "Successful Use of Teams in a Human Computer Interaction REU: Combining Intensive Instruction with Strong Mentoring," Proceedings of the 2009 ASEE Annual Conference \& Exposition, Austin, TX.

[10] Barry, C., and Isaacs, J., 2008, "Improving the Professional Development Component of an REU Summer Program," Proceedings of the 2008 ASEE Annual Conference \& Exposition, Pittsburgh, PA.

[11] Guerrero, C., Labrador, M., and Perez, R., 2007, "Enhancing the Global Perspective of REU Site Students," Proceedings of the 2007 ASEE Annual Conference \& Exposition, Honolulu, Hawaii.

[12] Nerenberg, R., 2006, "Challenges and Opportunities in Working with Minority/Overseas REU Students," Proceedings of the 2006 ASEE Annual Conference \& Exposition, Chicago, Illinois.

[13] Zimmerman, B. J., 1994, Dimensions of Academic Self-Regulation: A Conceptual Framework for Education,” In Schunk, D. H. and Zimmerman, B. J. (Eds.), Self-Regulation of Learning and Performance: Issues and Educational Applications (pp. 3-21), Lawrence Erlbaum Associates, Hillsdale, NJ.

[14] Schraw, G., Crippen, K., and Hartley, K., 2006, "Promoting Self-Regulation in Science Education: Metacognition as Part of a Broader Perspective on Learning," Research in Science Education, Vol. 36, pp. 111-139.

[15] Zheng, W., Shih, H. R., Skelton, G. W., and Yin, J., 2012, "Implementing Self-Regulated Learning Process Model and Assessment for Facilitating Civil Engineering Students to Master Engineering Concepts," Proceedings of the 2012 ASEE Annual Conference \& Exposition, San Antonio, Texas. 
[16] Zimmerman, B. J., and Martinez-Pons, M., 1986, "Development of a Structured Interview for Assessing Student Use of Self-Regulated Learning Strategies," American Educational Research Journal, Vol. 23(4), pp. 614-628.

[17] Zimmerman B. J., 2001, “Achieving Academic Excellence: A Self-Regulatory Perspective,” In Ferrari, M. (Ed.), Pursuit of Excellence (pp. 85-109), Erlbaum, Mahwah, NJ.

[18] Lawanto, O., Butler, D., Cartier, S., Santoso, H. B., \& Goodridge, W. 2013. "Task Interpretation, Cognitive, and Metacognitive Strategies of Higher and Lower Performers in an Engineering Design Project: An Exploratory Study of College Freshmen," International Journal of Engineering Education, Vol. 29(2), pp. 459-475.

[19] Butler, D. L., and Cartier, S. C., 2004, "Learning in Varying Activities: An Explanatory Framework and a New Evaluation Tool Founded on a Model of Self-Regulated Learning," Paper presented at the Annual Conference of the Canadian Society for the Study of Education, Toronto, ON.

[20] Butler, D. L., and Cartier, S. C., 2005, "Multiple Complementary Methods for Understanding Self-Regulated Learning as Situated in Context," Paper presented at the Annual Meetings of the American Educational Research Association, Montreal, QC.

[21] Cartier, S. C., and Butler, D. L., 2004, "Elaboration and Validation of the Questionnaires and Plan for Analysis," Paper presented at the Annual Conference of the Canadian Society for the Study of Education, Toronto, ON.

[22] Kane, M. A., Beals, C., Valeau, E. J., and Johnson, M. J., 2004, "Fostering Success Among Traditionally Underrepresented Student Groups: Hartnell College's Approach to Implementation of the Math, Engineering, and Science Achievements (MESA) Program," Community College Journal of Research and Practice, Vol. 28, pp. 17-26. 